\title{
The Baby Boom, Baby Busts, and the Role of Grandmothers in Childcare*
}

\author{
Türkmen Göksel** \\ Ankara University
}

\author{
Mehmet Y. Gürdal*** \\ Boğaziçi University
}

\author{
Cüneyt Orman $* * * *$ \\ Central Bank of the Republic of Turkey
}

\begin{abstract}
Studies in family economics and anthropology suggest that grandmothers are a highly valuable source of childcare assistance. As such, the availability of grandmothers affects the cost of having children, and hence the fertility decisions of young parents. In this paper, we develop a simple model to assess the fertility implications of the fluctuations in both output (as argued by demographers) and grandmother-availability induced childcare costs over the period of 1920-1970. The model does a good job of mimicking the bust-boom-bust pattern during this period. When the child-care cost channel is shut down, the model's performance weakens significantly; in particular, it fails altogether to capture the bust in the 1960's.
\end{abstract}

Keywords: fertility, baby boom, baby bust, female labor-force participation, grandmother availability for childcare.

JEL Classification Numbers: J13, J20

\section{Çocuk Sayısındaki Patlama, Sert Düşüşler ve Büyükannelerin Çocuk Bakımındaki Rolü}

\section{Özet}

Aile iktisadı ve antropoloji çalışmaları büyükannelerin torunlarının bakımında çok önemli bir rol oynadıklarını göstermektedir. Büyükannelerin varlığı çocuk edinme maliyetlerini azaltmakta ve böylelikle genç ebeveynlerin çocuk yapma kararları üzerinde etkili olmaktadır. Bu çalışmada, üretim miktarındaki dalgalanmaların ve büyükannelerin varlığıyla şekillenen çocuk bakım maliyetlerinin birlikte 1920-70 yılları arasında doğurganlığı nasıl belirlediğine ilişkin basit bir model geliştirilmektedir. Model, bahsedilen süre zarfinda gözlenen düşüş-patlama-düşüş örgüsü ile uyumlu tahminler üretmektedir. Modelden çocuk bakım maliyetlerine ilişkin unsurlar çıkarıldığında, modelin gerçek veriyle uyumu

\footnotetext{
* We thank the seminar participants at the Turkish Economic Association's International Conference on Economics in Girne and the Middle East Economic Association's Meeting in Istanbul, and the two anonymous referees for their helpful comments and suggestions. The views expressed herein are solely those of the authors and do not represent those of the Central Bank of the Republic of Turkey or its staff.

** Türkmen Göksel is an Associate Professor in the Department of Economics at Ankara University, Cemal Gursel Bulvari, 06590 Cebeci, Ankara, Turkey. E-mail: turkmen_goksel@yahoo.com

*** Mehmet Y. Gürdal is an Assistant Professor in the Department of Economics at Boğaziçi University, 34342, Bebek, Istanbul, Turkey. E-mail: mehmet.gurdal@boun.edu.tr

**** Dr. Cüneyt Orman is an Advisor at the Central Bank of the Republic of Turkey, Istiklal Cad. No. 10, 06100 Ulus, Ankara, Turkey. E-mail: cuneyt.orman@tcmb.gov.tr
} 
ciddi biçimde azalmakta, özellikle 1960’larda gözlenen çocuk sayısındaki sert düşüşün yakalanması olanaksız hale gelmektedir.

Anahtar kelimeler: doğurganlık, çocuk sayısındaki patlama, çocuk sayısındaki sert düşüş, kadınların işgücüne katılımı, büyükannelerin çocuk bakımındaki rolü.

JEL Sinıflaması: J13, J20

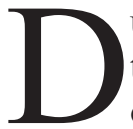

uring the 20th century, fertility in the United States and in many other industrialized nations has exhibited a series of unprecedented deviations around an otherwise declining trend. The most striking of these deviations is the large upward swing in fertility beginning roughly in the early 1940's and lasting until the early 1960's. This "baby boom" was followed by a sharp downturn after the early 1960's, the "baby bust", which brought fertility back to its normal trend by the 1980's.

Existing theories of the baby boom and baby bust often attribute these events to fluctuations in productivity that occurred with similar timing - the boom following World War II and the slowdown of the 1970's. Quantitative models appear to lend some support to these theories, but they also suggest that productivity fluctuations are only part of the story. Calibrating a model that combines simple versions of the stochastic growth model and the Barro-Becker model of endogenous fertility, Jones and Schoonbroodt (2007) find that deviations in productivity capture about 40 percent of the baby boom. Their model, however, predicts the continuation of the boom well into the 1960's, which is in stark contrast to the data. Greenwood et al. (2005) take into account the fertility implications of deviations in household sector productivity in addition to those in market sector productivity. They argue that the introduction of electricity and associated household appliances reduced the need for labor in the child-rearing process; the implied lower cost of having children must then have led to an increase in fertility, and hence the baby boom. This idea is subsequently quantified in a model that combines elements of the standard overlapping-generations model of population growth and a standard household production model. Although the pattern of fertility generated by their preferred model matches the long-run trend in the U.S. data, the model underestimates the baby boom. An alternative specification of their model provides a better match to the boom, but it also causes the model to underestimate the decline in fertility during the baby bust.

Doepke et al. (2005) propose an alternative theory based on the increased demand for female labor during World War II. They argue that women who were old enough to work during the war accumulated valuable market experience, and consequently many of them continued to work after the war. Younger women who turned adult only after the war and entered the labor market then faced competition not only from the men who returned from the war but also from the experienced women of the war generation who were still in the labor force. They argue that this led to less demand for inexperienced young women who were thus crowded out of the labor market and chose to have more children instead. They add that it is these younger women who account for the bulk of the baby boom. They formalize these ideas in a model of fertility choice along the lines of Galor and Weil (1996) and find that the mechanism can account for a substantial portion of the baby boom and bust events. 
A main weakness in most of the papers in this literature is their inability to capture the baby bust occurring in the 1960s: While some models underestimate the baby bust, others fail to capture it altogether, driving fertility the wrong way. In this paper, we argue that by incorporating the changes in the availability of extended family members such as aunts and grandmothers and female neighbors and friends for child-rearing that took place during this period into these models, we can improve their ability to account for the data, particularly in the bust period. The basic idea is that the availability of aunts, grandmothers, and friends (henceforth grandmother availability for short) in the home or vicinity should reduce the cost of having kids and hence cause an increase in fertility, other things being constant. It is important to emphasize that our notion of grandmother availability is one that takes into account not only the supply of childcare by grandmothers but also the demand for childcare by young mothers, which we more formally discuss in sections 2.1 and 4.1. Since there was a sharp drop in grandmother availability between the late 1950s and the late 1960s after half a century of roughly constant levels (as will be argued in sections 2 and 4), the cost of having kids must have gone up sharply in this period, potentially leading to a bust in fertility.

In order to find out if this hypothesis has any promise confronting the data, at least in a qualitative sense, we use a simple model in which fertility is determined jointly by fluctuations in productivity and child-care costs. The novel aspect of our approach is that we assume that fluctuations in child-care costs are generated by fluctuations in grandmother availability. In particular, following Heckman (1974) and others in the family economics literature, we postulate a negative relationship between the two variables, whereby higher (lower) levels of grandmother availability are associated with lower (higher) levels of child-care costs. After quantifying the model using U.S. data, we find that the pattern of fertility generated by the model matches quite closely that in the data over the period 1920-1970, thereby replicating the well-known bustboom-bust pattern; however, we note that there are differences in the levels of the two series. ${ }^{[1]}$ When we shut down the child-care cost channel induced by movements in grandmother availability, the match between the model-generated and actual fertility series worsens considerably and the model fails to capture the baby bust in the 1960's altogether, driving fertility the wrong way. We interpret these findings as evidence that fluctuations in child-care costs induced by movements in grandmother availability play a particularly important role in the baby bust event of the 1960's.

The remainder of the paper is organized as follows. In Section 2, we first provide empirical evidence concerning trends in grandmother availability for child-care assistance. We also shed some light on the reasons causing the drastic change in the availability of grandmothers that took place during the 10-15 year period following the late 1950's. We then present both theoretical and empirical evidence on the relationship between grandmother availability, child-care costs, female labor force participation,

[1] The difference in levels should not be surprising since the model is not constructed and simulated so as to match the data quantitatively, but rather to provide a sense of the potential contribution of the fluctuations in grandmother availability to the baby boom and bust events. 
and fertility. In Section 3, we develop the formal model of the relationship between fertility, productivity, child-care costs, and grandmother availability. A series of quantitative experiments are conducted on our theoretical model in Section 4. This section also introduces our formal definition of grandmother availability and explains how we measure it from data. Section 5 presents concluding remarks.

\section{Theoretical and Empirical Evidence}

\section{Changes in Grandmother Availability}

We hypothesize that (i) grandmothers will be less likely to offer help in child-rearing if they are working or looking for work themselves, and (ii) mothers will be more likely to need child-care assistance if they are working or looking for work themselves. Grandmother availability will then be a product of the interaction between the ability of grandmothers to offer childcare (the supply of childcare) and the extent to which mothers need that care (the demand for childcare). We provide the precise technical definition of this concept in Section 4.1. In order to get a sense of grandmother availability for child-care assistance over time, we utilize census data from the Integrated Public Use Microdata Series (IPUMS) of the Minnesota Population Center. This data set provides information on labor force participation rates of women for various age groups on a decennial basis. Figure 1 displays the evolution of the labor force participation rates of young-age (18-32 years) and old-age (33-60 years) females between 1910 and 1970 .

Figure 1

Labor Force Participation by Young (18-32 years) and Old (33-60 years) Women in the United States (includes women of all races and marital statuses)

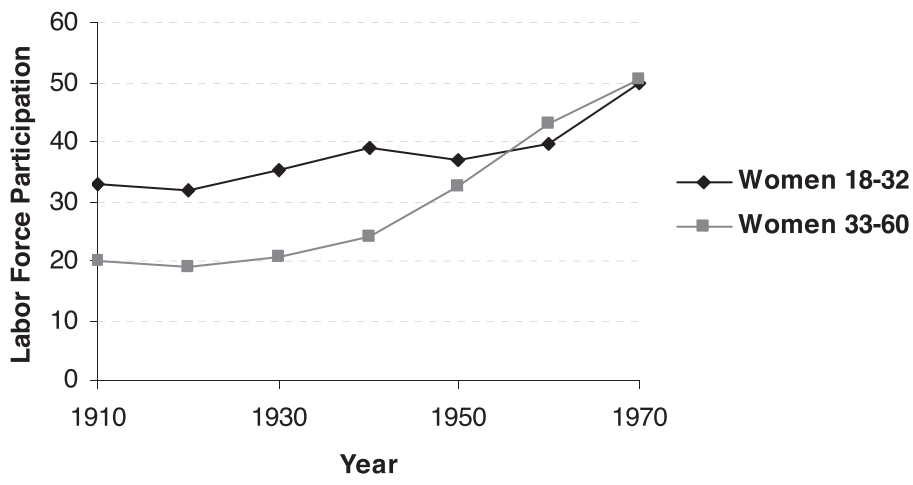

The figure indicates that (i) between the 1920's and 1940's, the labor force participation rates for both young and old-age females grew relatively slowly but steadily, and with roughly equal growth rates; (ii) between the 1940's and 1960's, there was a 
pick-up in the growth rate of the participation rate of older women (33-60) while the participation rate of younger women (18-32) stagnated; and (iii) in the 1960's, there was a sharp increase in the growth rate of the participation rate of younger women while the growth rate of the participation of older women roughly kept its pace of the previous two decades. Therefore, the symmetric evolution of the labor force participation of younger and older women goes through a breakdown around 1940. ${ }^{[2]}$ To the extent that the young-age women represent potential mothers and the old-age women represent potential grandmothers in the population, these three observations suggest a simultaneous increase in the demand for non-parental child-care (potential moms are more likely to be working) and a decrease in the supply of such care (potential grandmothers are more likely to be working) over the time period of 1910-1970. In other words, non-parental child-care provided by grandmothers becomes increasingly scarce (relative to demand) during this period. The most striking change, however, occurs in the 1960's: Quite differently from previous decades, grandmother availability declines sharply during this period, thanks to the simultaneous sharp increases in the labor force participation rates of both young-age and old-age women. In the absence of other forms of child-care, such as those provided in formal markets, the decline in grandmother availability must have worked to increase the cost of having kids between 1910 and 1970 , and particularly after the late 1950's.

\section{Formal Child-care Availability before the 1970's}

In our analysis, we focus on the period before 1970. The scarce evidence suggests that the size of the (formal) child-care industry was quite small up until the early 1970's. For example, Low and Spindler (1968) find in their survey that in 1965, for 10.5 million mothers with children 0-17 years of age, licensed day care facilities were available for only 475,000 children. They also report that 80 percent of children were cared for either by themselves, or by their immediate or extended family (mother, father, or other relative). Ruderman (1968) reports similar findings concerning the forms of child-care available during that period. Kamerman (1983), on the other hand, provides evidence to the effect that the child-care industry grew rapidly beginning in the early-to-mid 1970s. An important factor contributing to this change appears to have been the government programs (such as workfare legislations and child-care tax credits) initiated in the early 1970's under the Nixon administration. Since these programs subsidize market-provided child care, but not that provided by unpaid relatives, they change the relative price of market and nonmarket provided care (Klerman and Leibowitz, 1990). This change, coupled with the fact that labor force participation by women has also been growing, points to its having been an important force behind the rapid growth of the child care industry observed in the 1970's.

[2] Doepke et al. (2005) also point to this fact. They argue that the surge in the labor market participation of older women in the 1950's was due in large part to a long-term effect of WWII. In particular, they argue that the women who worked during the war accumulated valuable labor market experience, and consequently many of them continued to work after the war. 


\section{Child-care Availability, Grandmothers, and Employment Decisions}

Previous research shows that child care costs have a significant effect on the employment decisions of women. Low and Spindler (1968) report that the younger the children the less likely a mother was to be working a full year rather than part year. Ruderman (1968), Bowen and Finegan (1969), and Gronau (1973) find that only younger children (those under 3) exert an important retarding effect on women's work efforts. These findings might be explained by the fact that child-care costs are the highest for this group of children (See, for example, Del Boca et. al., 2005).

Child care costs also affect the fertility decisions of women. Blau and Robins (1989, 1990) provide evidence that fertility is negatively related to the price of child care. Connelly (1992) finds that fertility and employment decisions are intertwined and that higher child care costs discourage employment.

In the absence of a formal child care market, other arrangements for child care become important in determining the fertility and employment decisions of young women. Low and Spindler (1968) report that 80 percent of the children of working mothers were cared for by themselves or by their immediate or extended family and that the most frequent type of child care used was by a relative other than the father, and that a substantial fraction of that care was provided by grandparents (presumably grandmothers). They also report that the lowest level of dissatisfaction for care provided by people other than themselves was about the care provided by other adult relatives such as the grandmothers. Rodes (1975) reports a similar finding concerning care provided by adult relatives. Consistent with this body of work, Mason and Kuhlthau (1992) find in their sample of working mothers that about one-third name relatives such as the grandmother rather than the child's father as the ideal caregiver for children under the age of three. There is also evidence that the presence of the grandmother in the household is associated with higher likelihoods of mothers being in the labor market (Van Gameren and Ooms, 2009), and earlier returns to work among working women with preschool-aged children, especially those with young preschoolers (Klerman and Leibowitz, 1990). Among those returning to work before their infant was three months old, more than half the women used a relative to care for their child (Leibowitz et al., 1992). They also report that having one's own mother nearby had a large impact on the types of child care chosen for the very young. However, later decisions about the type of provider are independent of the availability of the grandmother.

\section{Arguments from Anthropology}

The evidence coming from studies in anthropology confirms the effect of grandmothers on fertility decisions of young women. These studies are mainly motivated by the observation that a major difference between human beings and other mammals is that female members of human societies live long beyond their reproductive capacity. This is evidenced in the comparison of reproductive and postmenopausal life spans of the human species with other primates. Although different primates have reproductive phases of the same lengths during their life time, female human species have exceptionally long postmenopausal life spans (Schultz, 1969). 
A proposed explanation for this phenomenon, the Grandmothering Hypothesis, suggests that the post-reproductive component of life for females is favored by natural selection due to the positive effects of grandmothering on the fitness of the offspring (Hawkes et al., 1998). This effect has likely emerged as human societies were shifting from simple to hard-to-handle food, giving an opportunity for vigorous elder females to help their daughters and increasing the representation of their vigor in descendant generations (Hawkes, 2004).

Using individual-based multi-generational data sets from pre-modern (18th and 19th centuries) populations of Finland and Canada, Lahdenpera et al. (2004) study the fitness benefits of post-reproductive lifespan for females. They find that the presence of a grandmother increases the number of grandchildren and reduces interbirth intervals for the grandchildren. In addition to this, grandchildren have significantly higher survival probabilities if their grandmother is alive at their birth.

\section{The Model}

In this section, we lay out a very simple model of the response of fertility to movements in Total Factor Productivity (TFP) and grandmother availability. The model we use has the two important components of productivity shocks and child-care cost shocks, where the latter is assumed to be induced by changes in grandmother availability. In each period, after the shocks are realized, the representative household decides how much to consume and how many children to have. ${ }^{[3]}$

The household's problem can be formulated as follows. In each period, the household solves the utility maximization problem:

$$
\max _{c_{t}, n_{t}} \alpha \ln \left(n_{t}\right)+(1-\alpha) \ln \left(c_{t}\right)
$$

subject to: $p_{t} n_{t}+c_{t}=s_{t} y_{t}$

where $s_{t}$ is the productivity shock, $p_{t}$ is the child-care cost, $c_{t}$ is consumption, $n_{t}$ is the number of children, $y_{t}$ is the level of income in period $t$ and $\alpha$ is a scalar between 0 and $1 .{ }^{[4]}$ The maximization takes place after the realization of $s_{t}$ and $p_{t}$. Equation (1) is the budget constraint.

The cost of having children, $p_{t}$, is assumed, for simplicity, to be in terms of goods. ${ }^{[5]}$ The cost $p_{t}$ is associated with producing children and is best interpreted as representing child-related costs that begin around birth and continue during the early preschool years of a child. The key assumption we make is that if a grandmother is around to help with looking after children, then this cost is reduced for parents. We model this effect

\footnotetext{
${ }^{[3]}$ Note that since the shocks are realized before the household decision process, our model is in fact a deterministic one. Therefore, the word "shock" should not be interpreted literally.

${ }^{[4]}$ The price of consumption is normalized to 1 .

[5] An alternative but equivalent approach would be to model these costs in terms of time spent; please see Jones and Schoonbroodt (2007). This way of modeling allows us to abstract from the labor market aspects of fertility choice without affecting the substantive conclusions.
} 
by letting $p_{t}$ be a decreasing function of grandmother availability, $G_{t}$; that is, we let

$$
p_{t}=f\left(G_{t}\right) \text {, }
$$

where $f()>$.0 and $f^{\prime}()<$.0 .

The solution for the optimization problem is standard and is given by:

$$
\begin{aligned}
& c_{t}=(1-\alpha) s_{t} y_{t}, \\
& n_{t}=\frac{\alpha y_{t} s_{t}}{p_{t}} .
\end{aligned}
$$

The key variable of interest is the fertility rate, $n_{t}$, given by equation (4). This is the model quantity that we will identify with the Total Fertility Rate (TFR) in the data in the next section. Note that $n_{t}$ increases with the realized level of income, $s_{t} y_{t}$, and decreases with the cost of producing children, $p_{t}$. Assuming that fertility should be increasing along with income might seem strange in the face of the fact that most studies find a negative relationship between the two variables, especially if one is trying to understand the secular decline in fertility rates in industrialized countries since the early 1800's. Since our focus is on the period between 1910 and 1970, however, we do not view this as a serious problem for our analysis. This is because the coefficient of correlation between the two annual series for TFR and TFP for the years 1917 to 1968 is 0.35 , which suggests that the U.S. TFR is procylical during this period. ${ }^{[6]}$

\section{Quantification}

In this section, we perform a number of simple quantitative experiments on the model developed in the previous section. Our ultimate goal is to find out whether including grandmother availability in an otherwise standard model of fertility choice can improve the ability of the model to account for the data during the baby boom and bust episode. Consistent with this goal, we first calculate the actual magnitudes of deviations from the trends of TFP and child-rearing costs for every decade from the 1910's to the 1960's. Then, we feed these into the model to obtain model results for fertility rates. Next, we compare the fertility series generated by the model with the actual time series of fertility rates. Finally, in order to highlight the significance of child-rearing costs for fertility, we consider a version of the model in which shocks to child-rearing costs are completely shut down, and compare the results with that of the baseline model. While performing these exercises, we also briefly describe the main features of the relevant variables in the data, namely, TFP, TFR, and availability of child-care assistance provided by grandmothers.

\section{Model with both TFP and Child-rearing Cost Shocks}

A critical choice here is the length of a period. Like Greenwood et al. (2005) and Jones and Schoonbroodt (2007), we assume that a period is 10 years. In addition, without loss

\footnotetext{
[6] Please see also Jones and Schoonbroodt (2007) on this point. They find that the coefficient of correlation between the
} annual series of the deviations of the two variables from their respective trends is 0.67 for the same period. 
of generality, we set $\alpha=1 / 2$ in order to fully characterize the decision rules. ${ }^{[7]} \mathrm{Next}$, we must obtain the realizations of the shocks to TFP, child-rearing costs, and incomes for all decades beginning with 1910-1919 and ending with 1960-1969. To this end, we first use the TFP data as laid out in Kendrick (1961) and Kendrick (1973). This data series is available at annual frequencies and is shown in Figure 2 over the period 1889 to 1969.

Figure 2

Total Factor Productivity, 1889-1969

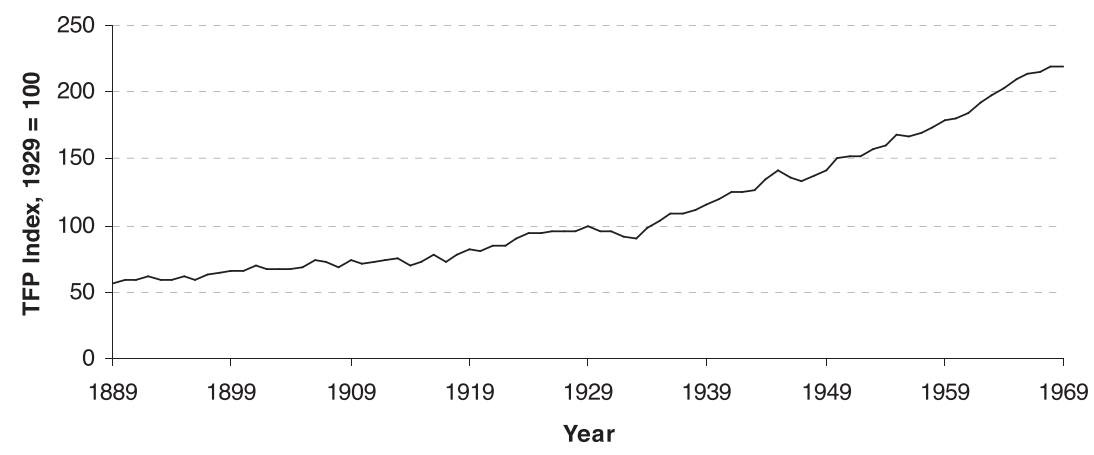

The main features of this data series are:

- A general upward trend,

- An downward trend during the 1920's and 1930's, and

- A return to trend following World War II.

We use this data series to obtain the realizations of the TFP shocks for the period 1910-1970. In particular, we first define

$$
s_{t}=\frac{A_{t}}{\bar{A}_{t}}
$$

where $A_{t}$ denotes the realization of TFP in period $t$ and $\bar{A}_{t}$ denotes the value predicted by the trend of TFP in period $t$. Thus, $s_{t}$ takes the value of 1 if there is no shock; that is, when $A_{t}=\bar{A}_{t}$. Depending on the nature of the shocks, which can be positive or negative, the value of $s_{t}$ moves around 1 . Note that while $A_{t}$ comes directly from Kendrick's data, $\bar{A}_{t}$ must be calculated. To do this, we fit an exponential trend to the TFP series. We finally use equation (5) to compute $s_{t}$ decade by decade, beginning with 1910 to 1919. The estimated series for $s_{t}$ is given by $[0.935,0.966,0.905,0.987,1.026,1.079] .^{[8]}$

Obtaining the series for the child-rearing costs, $p_{t}$, is slightly more involved. We do this in a number of steps. First, recall that we argued in the previous sections that

\footnotetext{
[7] Note that our results in fact hold for any $\alpha>0$.

${ }^{[8]}$ In order to find the decade $s_{t}$ values, we first calculate the $s$ values year by year for each decade and then take the average of these ten values.
} 
child-rearing costs are negatively related to grandmother availability. Here, we specify this relation as

$$
p_{t}=f\left(G_{t}\right)=\bar{p}+\varepsilon\left(G_{t}\right)
$$

where $\bar{p}$ is the constant long-run level of the child-care cost, which is without loss of generality normalized to 1 , and $\varepsilon\left(G_{t}\right)$ is the shock to this cost induced by movements in grandmother availability. Therefore, we assume that changes in the cost of childcare come only from changes in the availability of grandmothers for child-rearing. ${ }^{[9]}$ Just like the value of $s_{t}$, the value of $p_{t}$ moves around 1: While an above-trend value of $G_{t}$ decreases $p_{t}$ (in which case $\varepsilon\left(G_{t}\right)<0$ ), a below-trend value of $G_{t}$ increases it (in which case $\left.\varepsilon\left(G_{t}\right)>0\right)$.

In order to determine whether $\varepsilon\left(G_{t}\right)$ is positive or negative, we must first obtain a quantitative measure of grandmother availability, $G_{t}$. Unfortunately, grandmother availability is not a routinely reported statistic. We must therefore construct it ourselves. Our approach to constructing such a measure is based on two premises:

- Grandmothers will be more likely to offer child-care assistance if they are not working or looking for work, and

- Mothers will be more likely to need child-care assistance if they are working or looking for work.

Consistent with these premises, we use labor force participation data for younger and older women (representing potential mothers and potential grandmothers, respectively) from IPUMS for the decades 1910 to 1970 to construct our statistic. Since IPUMS dataset is based on Census surveys, the data are available only every 10 years. ${ }^{[10]}$ To construct our statistic, we compute

$$
G_{t}=\frac{(\text { Women who are not in the labor force and are aged between } 33-60)_{t}}{(\text { Women who are in the labor force and are aged between } 18-32)_{t}}
$$

for each time point 1910, 1920, 1930, 1940, 1950, 1960 and 1970. Here, the numerator proxies the supply of child-care and the denominator proxies the demand for child-care. As such, this statistic can be interpreted as an "effective supply" or "availability" of child-care assistance provided by grandmothers in the present context. Note that by construction this measure takes into account child-care assistance provided not only by extended family members such as aunts and grandmothers, but potentially also that provided by female neighbors or friends. Figure 3 shows the time path for this series. Observe that the availability of child-care assistance is essentially constant between 1910 and 1960, with a sharp decline thereafter. As we will see shortly, this change likely has important implications for trends in fertility.

\footnotetext{
[9] There might of course be other factors impacting the cost of child-care. However, this way of modeling allows us to isolate the effects on fertility of fluctuations in grandmother availability.

${ }^{[10]}$ Also, since this dataset comes from a stratified sample, the data are weighted using the appropriate weighting scheme. See Ruggles et al. (2004) for details.
} 
Figure 3

\section{Grandmother Availability}

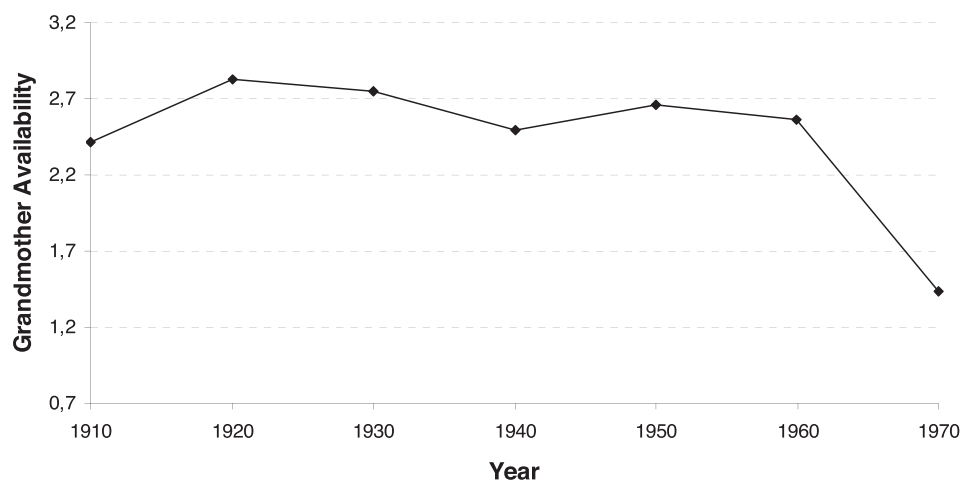

Having developed the grandmother availability statistic, we are ready to define $\mathcal{E}\left(G_{t}\right)$ which was first introduced in equation (6). First, using the fact that $G_{t}$ is roughly constant during most the period between 1910 and 1970, we take the average of the values for 1910-1970 in order to obtain the "trend" value of $G_{t}$ for the period. ${ }^{[11]}$ Let $\bar{G}$ denote this trend value. We can then define

$$
\varepsilon\left(G_{t}\right)=\frac{\bar{G}}{G_{t}}-1 .
$$

Observe that $\varepsilon\left(G_{t}\right)>0$ when $G_{t}<\bar{G}$ and $\varepsilon\left(G_{t}\right)<0$ when $G_{t}>\bar{G}$. We finally use equation (7) in conjunction with equation (6) to compute $p_{t}{ }^{[12]}$ The estimated series for $p_{t}$ is given by $p=[0.941,0.878,0.937,0.952,0.938,1.329]$. We should emphasize that our quantitative results are robust to various specifications of the age brackets: We have also checked appropriate combinations of (20-32), (18-35), (20-35) age brackets for younger women and (36-60), (40-60), (40-65) for older women. Figure 4 shows the deviations of $s_{t}$ and $p_{t}$ from their respective trends.

Finally, we need to calculate the value of income, $y$, for each decade. Towards this end, we first use the fact that our ultimate results regarding fertility do not depend on the specific pattern of $y$ (either constant or balanced growth over time) and simplify analysis by assuming a constant $y$ value for all decades. We then calibrate the model and pick the $y$ value that equates the average model-generated fertility rate to the actual average fertility rate during 1910-1969. Since the average fertility rate is 2.95 in the data, we find, using equation (4), that income has to be equal to 5.9 during 1910-1969. Figure 4 shows the deviations of $s_{t}$ and $p_{t}$ from their respective trends.

\footnotetext{
${ }^{[11]}$ Other ways of obtaining the trend for the period (such as fitting a polynomial trend to the series) do not affect the qualitative results of our analysis.

${ }^{[12]}$ Since the $G$ values are available only every ten years, we compute the decade $p_{t}$ values by taking the average of two consecutive $p$ values for each decade.
} 
Figure 4

Total Factor Productivity and Child-care Cost: Deviations from Trend

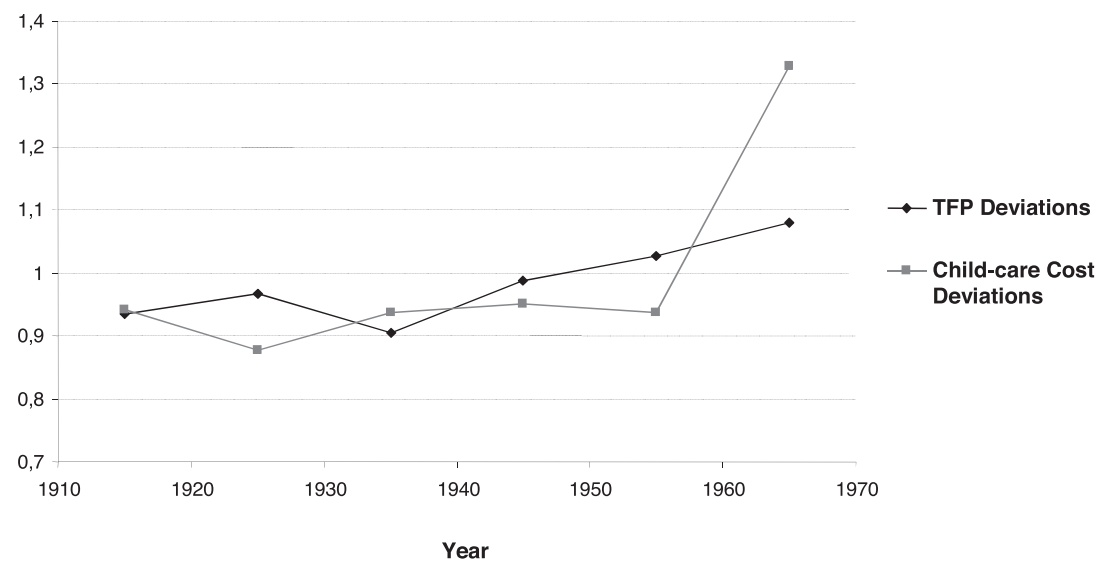

We are now ready to compare the model-generated fertility series versus the actual time series of fertility rates. To do this, we first obtain model results for fertility rates decade by decade by feeding the realizations of $s_{t}$ and $p_{t}$ into the model. Next, in order to obtain the actual time series of fertility rates, we use Total Fertility Rate (TFR) data from Natality Statistics Analysis from National Center for Health Statistics. ${ }^{[13]}$ This data series is available at annual frequencies, beginning with 1917. We complement this series by another time series prepared by Haines (1994). Since Haines uses census data, the time series is available only every 10 years. Figure 5 shows our TFR series over the period 1910 to 1970 .

Figure 5

Total Fertility Rate, 1910-1970

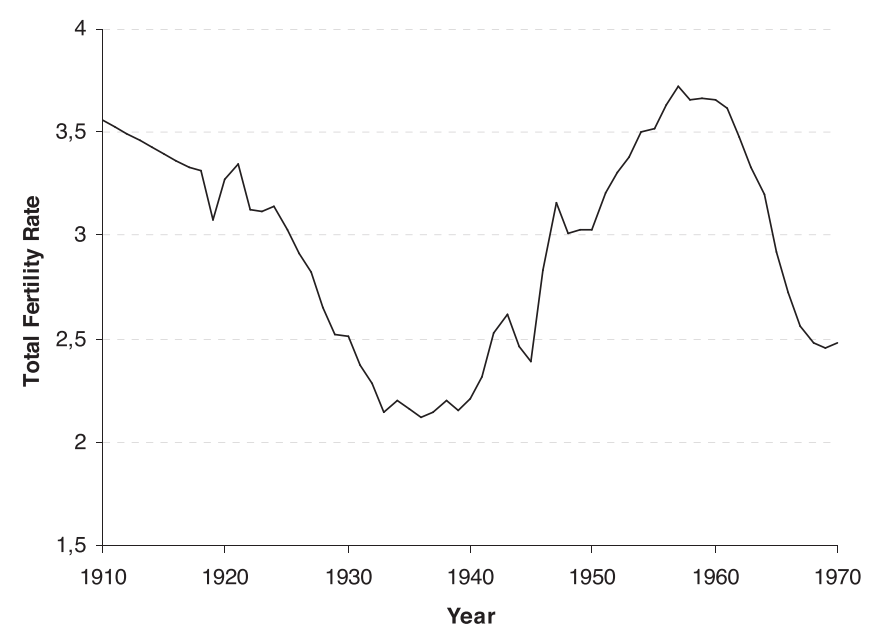

${ }^{[13]}$ We thank Alice Schoonbroodt for providing this time series to us. 
The main features of this data series are: ${ }^{[14]}$

- A downward trend until the mid 1930's,

- An upward trend between the late 1930's and late 1950's, and

- A downward trend after the late 1950's.

In order to make model and data quantities comparable, we then calculate the decade averages of the TFRs beginning with 1910 to 1919 and ending with 1960 to 1969. Using these findings, Figure 6 plots the fertility time series generated by our model and those observed in the data. As can be seen in the figure, the model is quite successful in predicting the general pattern in fertility, except for the first decade. In particular, the model predicts a baby boom beginning around the mid-1930's and lasting until the mid-1950's, and a baby bust beginning around the mid-1950's, just like in the data. The model also predicts an early baby bust between the 1920's and 1930's. Overall, the model is quite successful in capturing the main features of the bust-boom-bust event that took place in the United States around the middle of the 20th century.

Figure 6

Total Fertility Rate, Model versus Data

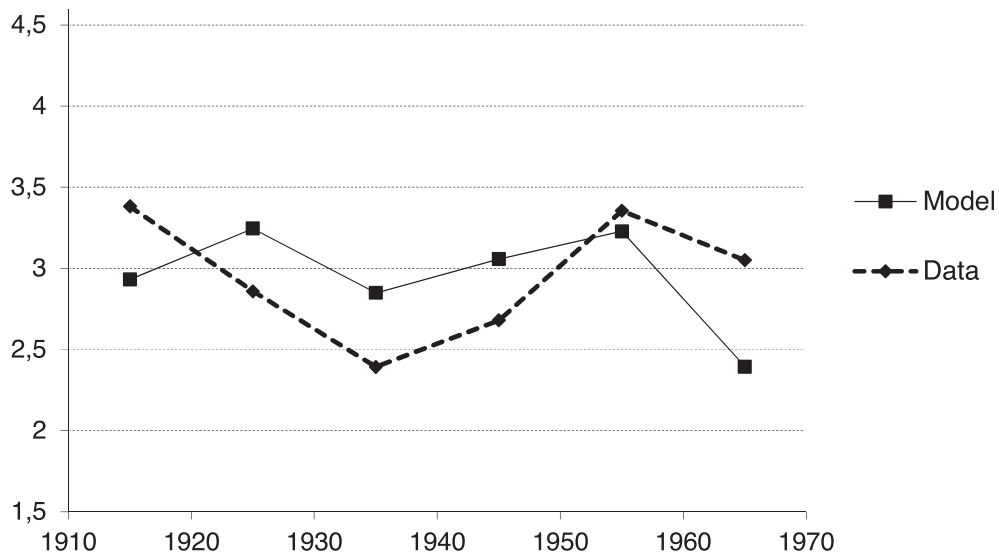

\section{Discussion: Model with only TFP Shocks}

In order to highlight the importance of child-rearing costs (and hence grandmother availability) for fertility, we now consider a version of our model in which these costs are assumed to be constant over time. Specifically, we ignore the volatility in child-rearing costs by setting $p=1$ for all decades (that is, we set $\varepsilon\left(G_{t}\right)=0$ for all $t$ ). Therefore, in this version of the model, movements in fertility rates arise solely as a result of shocks to TFP. Here, we keep the values of all parameters the same as in the previous version, except that we recalibrate the $y_{t}$ values taking into account the fact that now $p=1$ for all decades. In doing so, we obtain $y_{t}=6$ which is very close to the value 5.9 obtained

${ }^{[14]}$ The exact timing of these events depends on how exactly one looks at the data. For example, while Greenwood et al. (2005) start the baby boom in 1936, Jones and Schoonbroodt (2007) start it a few years later. Readers are referred to these two papers for a detailed description of this data series. 
in the previous section. Note also that this version of the model is also interesting because it most closely corresponds to that in Jones and Schoonbroodt (2007). Figure 7 displays the pattern of fertility rates predicted by each of the two models as well as those observed in the data.

Figure 7

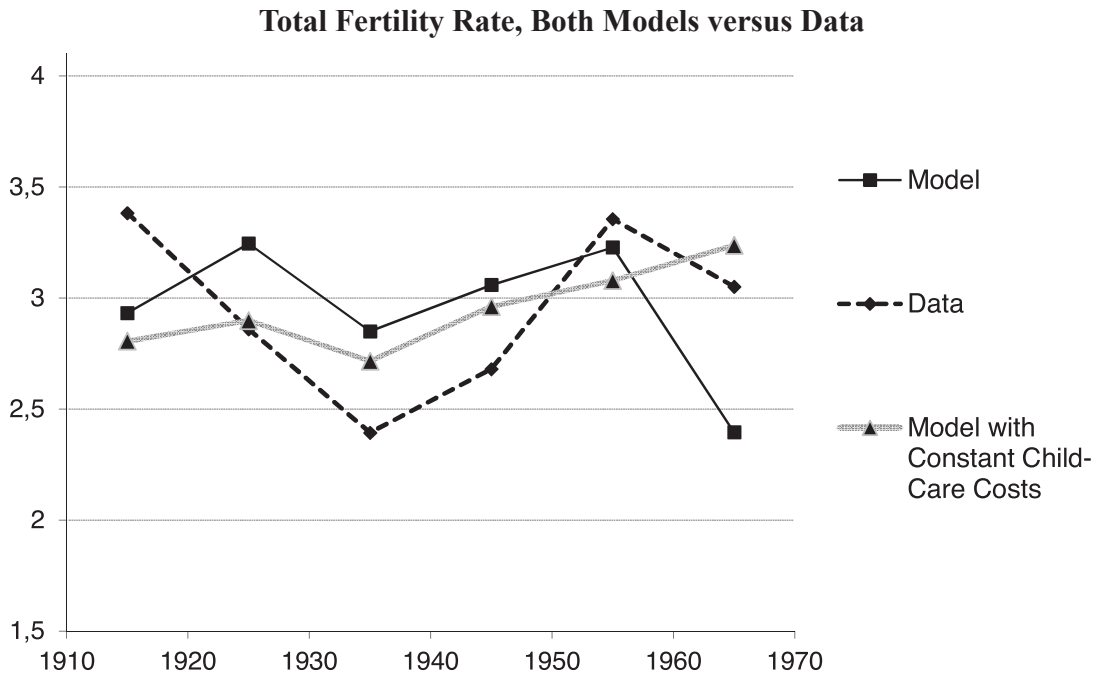

As can be seen from the figure, overall the version of the model with varying childrearing costs tracks more closely the fertility movements observed in the data than the version of the model with constant child-rearing costs. In particular, the figure shows that failing to take into account the fluctuations in child-rearing costs causes the gap between model-generated fertility rates and actual fertility rates to widen during the first baby bust that took place between the 1920's and 1930's as well as during the baby boom that took place between the 1930's and 1950's. The major difference between these two models arises, however, when we move from the 1950's to 1960's, that is, during the second baby bust. Contrary to what is in the data, the version of the model with constant child-rearing costs predicts an increase in fertility rates during this period. When grandmother availability-induced movements in child-rearing costs are included, however, the model predicts a decline in the fertility rate in this decade, as observed in the data. This finding suggests that the increase in child-rearing costs that took place during this period was large enough to reverse the positive effect on fertility coming from TFP shocks.

\section{Conclusion}

In this paper, we have developed a simple theory that links the baby boom and busts of the 20th century to fluctuations in productivity and child-rearing costs faced by young women making fertility decisions. 
Since there was a take-off in productivity in the 1940's and child-rearing costs were relatively low, our theory predicts a baby boom during this period. Likewise, the slowdown in the growth of productivity coupled with unusually high child-rearing costs faced by young women in the 1960's generates a baby bust. Our theory also predicts an earlier baby bust that took place between the 1920's and 1930's, just as observed in the data. Our quantitative experiments suggest that child-rearing costs are important in accounting for the bust-boom-bust events: The pattern of fertility generated by the version of the model with constant child-rearing costs provides a significantly worse match with the actual time series of fertility rates than that generated by the version of the model that features variable child-rearing costs. The main weakness of the former version of the model is that it fails to predict a baby bust in the 1960's, thus driving fertility the wrong way.

The novelty of our approach is that we link the cost of child-care to the extent of the availability of extended family members such as grandmothers and aunts (and also female neighbors and friends), an insight borrowed from the literatures on family economics and anthropology. Since formal sources of child-care were severely limited until the 1970's, focusing on such informal care is not only reasonable but also indispensable. We show that such care was relatively abundant during the baby boom, making it easier for young women to have children.

Following the surge in the labor force participation of older women in the 1940's, such informal child-care became increasingly scarce since older women now had less time to look after grandchildren. The scarcity of such care reached unusually high levels in the 1960's when the rapid growth in the labor force participation of older women was matched with an equally strong growth in the labor force participation of younger women, and therefore caused a baby bust.

The main conclusion from this paper should be that the presence of close relatives and friends affects social behavior. If we account for the temporal changes that took place in child-rearing costs induced by changes in the availability of aunts, grandmothers, and other adult women such as neighbors and friends we see the improved ability of an otherwise standard model of fertility to account for the data, particularly for the baby bust that occurred in the 1960's.

\section{References}

Blau, D., and Robins, P. (1989). "Fertility, Employment, and Child-care Costs," Demography, 26(2): 287-299.

------, (1991). “Child Care Demand and Labor Supply of Young Mothers over Time," Demography, 28(3); 333-351.

Bowen, W. and Finegan, T. (1969). The Economics of Labor Force Participation. Princeton: Princeton University Press.

Connelly, R. (1992). “Self-employment and Providing Child Care,” Demography, 29(1): 17-29.

Del Boca, D., Locatelli, M., and Vuri, D. (2005). "Child-Care Choices by Working Mothers: The Case of Italy," Review of Economics of the Household, 3(4): 1569-5239.

Doepke, M., Hazan, M., and Maoz, Y. (2007). “The Baby Boom and World War II: The Role of Labor Market Experience," NBER Working Paper 13707. 
Galor, O. and Weil, D. (1996). "The Gender Gap, Fertility, and Growth," The American Economic Review, 86(3): 374-387.

Greenwood, J., Seshadri, A., and Vandenbroucke, G. (2005). "The Baby Boom and Baby Bust," The American Economic Review, 95(1): 183-207.

Gronau, R. (1973). “The Intrafamily Allocation of Time: The Value of the Housewives' Time," The American Economic Review, 63(4): 634-651.

Hawkes, K. (2004). “The Grandmother Effect,” Nature, 428(6979): 128-129.

Hawkes, K., O’Connell, J.F., Jones, N., Alvarez, H., and Charnov, E. (1998). “Grandmothering, Menopause, and the Evolution of Human Life Histories," Proceedings of the National Academy of Sciences, 95(3): 1336.

Heckman, J. (1974). “Shadow Prices, Market Wages, and Labor Supply,” Econometrica, 42(4); 679-694.

Jones, L., and Schoonbroodt, A. (2007). "Baby Busts and Baby Booms: The Fertility Response to Shocks in Dynastic Models," Univ. of Southampton Discussion Papers in Economics and Econometrics, 0706.

Jones, L., Schoonbroodt, A., and Tertilt, M. (2011). "Fertility Theories: Can They Explain the Negative Fertility-Income Relationship?," forthcoming in Demography and the Economy, J. Shoven, (ed.), NBER.

Kamerman, S. (1983). “Child-care Services: A National Picture,” Monthly Labor Review, 106(12); 35-39.

Kendrick, J. W. (1961). Productivity Trends in the United States. Princeton University Press.

------, (1973). Postwar Productivity Trends in the United States, 1948-1969. NBER.

Klerman, J. and Leibowitz, A. (1990). "Child Care and Women's Return to Work after Childbirth." American Economic Review, Papers and Proceedings, 80(2): 284-288.

Lahdenpera, M., Lummaa, V., Helle, S., Tremblay, M., and Russell, A. (2004). "Fitness Benefits of Prolonged Post-reproductive Lifespan in Women," Nature, 428(6979), 178-181.

Leibowitz, A., Klerman, J., and Waite, L. (1992)." Employment of New Mothers and Child Care Choice: Differences by Children's Age," The Journal of Human Resources, 27(1): 112-133.

Low, S. and Spindler, P. (1968). Child Care Arrangements of Working Mothers in the United States. Superintendent of Documents, US Government Printing Office, Washington, DC 20402.

Mason, K. and Kuhlthau, K. (1992). "The Perceived Impact of Child Care Costs on Women's Labor Supply and Fertility.” Demography, 29(4): 523-543.

Rodes, T.W. (1975). American Consumer Attitudes and Opinions on Childcare, in National Childcare Consumer Study: 1975, vol. 3. Washington DC: Unco.

Ruderman, F. (1968). Child Care and Working Mothers: A Study of Arrangements Made for Daytime Care of Children. Child Welfare League of America, Inc., 44 E. 23rd St., New York, NY 10010.

Ruggles, S., Sobek, M., Alexander, T., Fitch, C., Goeken, R., Hall, P., King, M., and Ronnander, C. (2004). Integrated Public Use Microdata Series: Version 3.0, Minneapolis, MN: Minnesota Population Center.

Schultz, A. (1969). The Life of Primates. Universe Books.

Van Gameren, E. and Ooms, I. (2009). "Childcare and Labor Force Participation in the Netherlands: The Importance of Attitudes and Opinions," Review of Economics of the Household, 7(4): 395-421. 